\title{
Trends in de Nederlandse macro-economische ontwikkeling 1970-2000
}

\author{
Prof. Dr. E. Sterken
}

\section{Inleiding}

Sinds 1997 is de groei van het Nederlandse bruto binnenlands product (bbp) groter dan het naoorlogse gemiddelde van 2,5 procent. De Nederlandse groei volgt nauwgezet het patroon van de groei van de wereldeconomie. Men kan zelfs vaststellen dat in de laatste paar jaar de Nederlandse groei de wereldontwikkeling te boven gegaan is. Een mogelijke oorzaak van het goede presteren van de Nederlandse economie is de monetaire eenwording van West-Europa, waardoor de Nederlandse economie sinds 1999 de facto van een (te) lage (reële) interestvoet heeft kunnen profiteren. Indien men teruggaat in de tijd zijn er sinds 1970 zelfs maar twee perioden van vergelijkbare voorspoed in Nederland te vinden. De eerste periode van hoge groei is het begin van deze periode, 1970-1973. Zoals bekend zorgde de eerste oliecrisis van december 1973 voor een abrupt einde van deze conjuncturele opgang. De tweede periode vergelijkbaar met de huidige ontwikkeling omvat de jaren 1989-1990. Deze opgang werd beëindigd door de laatste recessie van de Amerikaanse economie in 1991. In de jaren negentig is er naderhand nog slechts een groeiaarzeling rond 1995 geweest. Sindsdien is de Nederlandse economie in de recente fase van hoogconjunctuur beland. Pas nu, in de loop van 2001, lijkt er aan die periode voorlopig een einde te komen.

Het voornaamste verschil tussen de afgelopen jaren en de vorige perioden van economische voorspoed is de huidige gematigde inflatie. Het lage inflatietempo kan worden verklaard door de snelle ontwikkeling van de technologie en de ver-

Prof. Dr. E. Sterken is Hoogleraar Monetaire Economie aan de Rijksuniversiteit Groningen. anderingen van het monetaire beleid. De sterke technologische vooruitgang zorgt immers voor een gematigde inflatie, omdat de kwaliteitsgroei sterker is dan de prijsverhoging. Een computer is sinds 1970 per jaar gemiddeld 30 procent goedkoper geworden. Deze prijsdaling zet zich uiteraard voort in een algehele prijsdaling. Het monetaire beleid van de meeste EU-landen is gericht op directe beheersing van inflatie. In vorige perioden hanteerde men veelal een indirecte inflatiebeheersing. De combinatie van een stevige groei met een gematigde inflatie is zeer aantrekkelijk.

Aanvankelijk heeft men dit aantrekkelijke scenario helemaal aan de ontwikkeling van de Informatie- en Communicatie Technologie (ICT) geweten. Na een periode van lage groei en oplopende inflatie (ook wel stagflatie genoemd) in het begin van de jaren tachtig was er dan ook duidelijke enthousiasme over de rol van de zogenaamde Nieuwe Economie. Het leek er dan ook op dat de groeiversnelling van de Nederlandse economie zich ook in 2001 en verder zou doorzetten. In de loop van 2000 werd evenwel duidelijk dat de Amerikaanse economie afkoelt, waardoor ook de groei van de wereldeconomie zal vertragen. Het is waarschijnlijk dat dit ook gevolgen zal hebben voor de Europese en dus ook voor de Nederlandse economie. Hiermee lijken de tegenstanders van het denken over de Nieuwe Economie voorlopig gelijk te krijgen.

In dit artikel wordt getracht een aantal macro-economische trends van de Nederlandse economie weer te geven. We proberen een aantal 'vaste' verbanden in woord en figuur weer te geven. Met behulp van het inzicht dat uit deze analyse van de trends kan worden afgeleid, is het mogelijk om de nabije toekomst althans in vogelvlucht te schetsen. In het navolgende wordt eerst de ontwikkeling van de internationale conjunctuur beschreven. We plaatsen de huidige ontwikkeling in een historisch perspectief. In het bijzonder wordt aandacht 
geschonken aan de ontwikkeling van de groei van de voor Nederland relevante wereldhandel, de ontwikkeling van de prijsstelling door concurrenten en de invloed van de olieprijs en de dollarkoers op concurrentiepositie. Tevens wordt aandacht geschonken aan de ontwikkeling van de Europese economie. Daarna wordt de ontwikkeling van de Nederlandse economie besproken. In de eerste plaats wordt de macro-economische ontwikkeling geschetst. Vervolgens bespreken we de ontwikkeling van de financiële markten. We sluiten af met enkele conclusies.

\section{De internationale conjunctuur}

De ontwikkeling van de internationale conjunctuur is voor een open economie als de Nederlandse van doorslaggevende betekenis. De huidige fase van hoogconjunctuur wordt grotendeels bepaald door de ontwikkeling van de voor ons land relevante wereldhandel. Figuur 1 geeft de groei van de relevante wereldhandel (EXC) en de groei van het bruto binnenlands product (BBP) voor de periode 1970-2000 weer. Uit figuur 1 blijkt dat de tegenvallende groei-episoden samenvallen met vertragingen van de wereldhandel. Achtereenvolgens zijn dat de perioden 1975, 1980-1983 en 1991-1993 geweest. De samenhang tussen de groei van de wereldhandel en de groei van het Nederlandse bbp komt tot uitdrukking in de zogenaamde Wet van Driehuis: de Nederlandse groei is ongeveer gelijk aan 40 procent van de groei van de relevante wereldhandel. Dit verband kan worden verduidelijkt door kennis te nemen van het uitvoeraandeel van het Nederlandse bbp (ongeveer 40 procent) en de zeer sterke samenhang tussen de groei van de wereldhandel en de groei van de Nederlandse uitvoer (zie figuur 2). Het voorspellen van de Nederlandse economische ontwikkeling is dan ook zeer sterk afhankelijk van de veronderstellingen die worden gemaakt met betrekking tot de ontwikkeling van de internationale conjunctuur. In de verklaring van de wereldconjunctuur is het dan weer hoofdzakelijk van belang om een goed beeld te krijgen van de Amerikaanse economie en de ontwikkeling van de Europese economie (met name het EU-gebied). De ontwikkeling van de Amerikaanse economie is van belang omdat in het verleden gebleken is dat deze een grote voorspellende waarde heeft voor de Europese ontwikkeling in de volgende twee jaren. Het Amerikaanse conjunctuurbeeld vertaalt zich eerst in een aanpassing van de Britse conjunctuur en vervolgens in een aanpassing van de continentaal Europese bedrijvigheid. Een belangrijke verklaring van deze gefaseerde aanpassing ligt in de wisselkoersmechanismen. Het Britse pond maakt geen deel uit van het startgebied van de euro. Hierdoor is de Britse economie gevoeliger voor de Amerikaanse fluctuaties. Door de beheerste bewegingen van het pond ten opzichte van de euro worden schokken evenwel vertraagd doorgegeven.

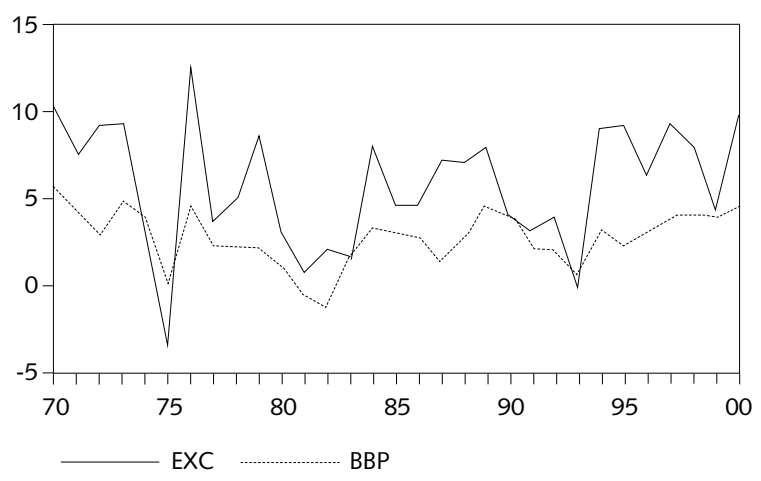

Figuur 1: Groei van de voor Nederland relevante wereldhandel (EXC) en het bruto binnenlands product (BBP) in procenten. Bron: CPB, Macro-Economische Verkenning 2001, 's-Gravenhage: SDU, 2000.

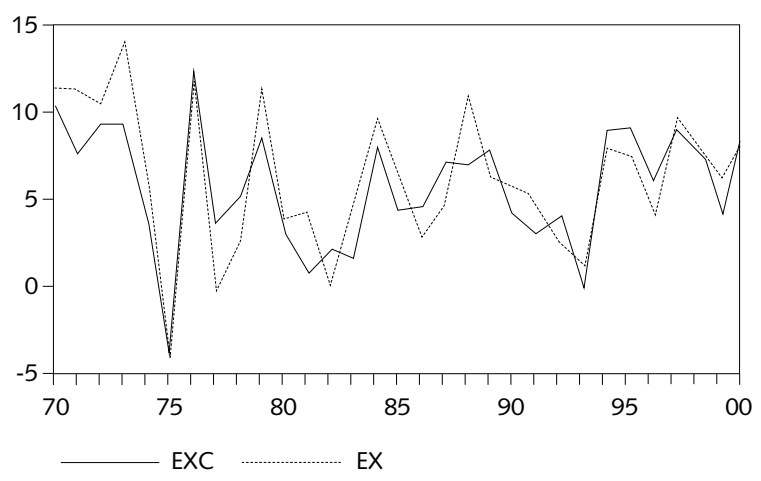

Figuur 2: Groei van de voor Nederland relevante wereldhandel (EXC) en de uitvoer, exclusief energie, (EX) in procenten. Bron: CPB, 2000.

We bespreken de internationale conjunctuur aan de hand van tabel 1. De cijfers in tabel 1 geven de belanrijkste indicatoren weer voor de VS, Japan en de elf landen van de Europese Unie, die de euro gebruiken. De cijfers voor 2001 zijn voorspellingen, zoals deze door The Economist op 24 februari 2001 gepubliceerd zijn.

De Amerikaanse economie heeft in het jaar 2000 een historisch hoog niveau van de bbp-groei laten zien. Sinds 1997 is de groei in de VS hoger dan 4 procent. Vooral de groei van de particuliere consumptie is hoog (boven de 5 procent in 1999 en 2000). Het opmerkelijke aspect van de periode van hoogconjunctuur is het samengaan van een 
Tabel 1: Internationale kerncijfers

\begin{tabular}{|c|c|c|c|c|}
\hline \multicolumn{5}{|c|}{ Verenigde Staten } \\
\hline & $B B P$ & Inflatie & Werkloosheid & Korte rentevoet \\
\hline 1996 & 3,6 & 2,1 & 5,4 & 5,4 \\
\hline 1997 & 4,4 & 1,9 & 4,9 & 5,6 \\
\hline 1998 & 4,4 & 1,1 & 4,5 & 5,5 \\
\hline 1999 & 4,2 & 1,8 & 4,2 & 5,3 \\
\hline 2000 & 5,0 & 3,4 & 4,2 & 6,2 \\
\hline 2001 & 1,8 & 2,5 & & \\
\hline \multicolumn{5}{|c|}{ Japan } \\
\hline & $B B P$ & Inflatie & Werkloosheid & Korte rentevoet \\
\hline 1996 & 5,1 & 0,1 & 3,4 & 0,6 \\
\hline 1997 & 1,6 & 1,7 & 3,4 & 0,6 \\
\hline 1998 & $-2,5$ & 0,2 & 4,1 & 0,7 \\
\hline 1999 & 0,2 & $-0,5$ & 4,7 & 0,3 \\
\hline 2000 & 1,7 & $-0,7$ & 4,7 & 0,5 \\
\hline 2001 & 1,4 & $-0,4$ & & \\
\hline \multicolumn{5}{|c|}{ EU-11 } \\
\hline & $B B P$ & Inflatie & Werkloosheid & Korte rentevoet \\
\hline 1996 & 1,4 & 2,1 & 11,7 & 4,8 \\
\hline 1997 & 2,3 & 1,9 & 11,7 & 4,3 \\
\hline 1998 & 2,6 & 1,1 & 11,0 & 3,9 \\
\hline 1999 & 2,3 & 1,8 & 10,1 & 2,9 \\
\hline 2000 & 3,4 & 2,3 & 8,7 & 4,7 \\
\hline 2001 & 2,6 & 1,9 & & \\
\hline
\end{tabular}

Bronnen: CPB, 2000, en The Economist van 24 Februari 2001 voor de ramingen van 2000 en 2001.

opmerkelijke bbp-groei en een gematigde inflatie. Door de snelle groei van de technologie neemt de arbeidsproductiviteit toe en is er een gematigde prijsontwikkeling van vooral die producten die een sterke technologische ontwikkeling doormaken. Dit is, zoals eerder opgemerkt, het standpunt van de Nieuwe Economie. Tegenstanders van deze theorie stellen dat de gematigde prijsontwikkeling tot halverwege 2000 te danken was aan een gematigde wereldinflatie. De sterke groei van de Amerikaanse economie is niet te danken aan een structureel hoger groeipad, maar wordt door louter tijdelijke effecten bepaald. De tegenstanders, waaronder Robert Gordon, zien de Amerikaanse opleving aldus meer als een conjunctuur- dan als een groeiverschijnsel. In de conjuncturele visie past een regelmatige afkoeling, waardoor de huidige groeivertraging niet onverwacht komt.

Niemand twijfelt momenteel meer aan een afkoeling van de Amerikaanse economie. De laatst gemeten groei van het bbp laat zien dat de groei afneemt van het hoge niveau van boven de 5 procent tot maximaal 2 procent in 2001. In de laatste maanden van 2000 vertraagde de groei al tot ruim
2 procent (op jaarbasis). Dankzij een sterke eerste helft van 2000 komt de bbp-groei van 2000 nog op ongeveer 5 procent uit. De voornaamste indicatoren van de groeivertraging zijn afnemende voorraden, afnemende nieuwbouwactiviteit, een vertraging van de groei van de werkgelegenheid en een tegenvallende ontwikkeling van de aandelenmarkt. De groeivertraging heeft inmiddels al tot forse rentestappen geleid. De Federal Reserve heeft in de eerste drie maanden van 2001 het officiële rentetarief al met 150 basispunten verlaagd. Er was enige zorg over de ontwikkeling van de Amerikaanse economie, omdat de sterke economische ontwikkeling tot medio 2000 zorgde voor een oplopende spanning op de arbeidsmarkt. Door de geweldige groei van de productie steeg de vraag naar arbeid dusdanig dat de werkloosheid daalde onder het niveau wat jarenlang was aangemerkt als het natuurlijke niveau (ongeveer 5 procent). Spanning op de arbeidsmarkt leidt tot een explosieve loonontwikkeling. Dit gevaar lonkte reeds eerder (in 1997), maar werd toen voorkomen door een daling van de invoerprijzen. Door de Aziatische crisis werd enige lucht geboden aan de ontwikkeling van de Amerikaanse inflatie. 
Vorig jaar veranderde dit beeld evenwel door de ontwikkeling van de olieprijs. Na de historisch lage prijs in 1998 steeg de olieprijs tot ruim 35 dollar per vat in 2000. Deze opwaartse druk heeft mede de Amerikaanse groei afgeremd. Hoe de inflatie zich verder zal ontwikkelen hangt af van de ontwikkeling van de arbeidsproductiviteit bij een dalende productie. Is de productiviteitsontwikkeling structureel, dan zal de conjuncturele tegenwind minder invloed hebben.

De Amerikaanse economie kende naast vele succesvolle elementen in de afgleopen jaren ook een paar nadelige ontwikkelingen, die hun invloed op de huidige groeivertraging kunnen hebben. Zo is er nog steeds een groot tekort op de lopende rekening van de betalingsbalans (ongeveer 5 procent van het bbp). In een groeiscenario is een dergelijk tekort evenwel niet belastend. Immers, beleggers zullen bereid zijn kapitaal naar de VS te brengen zolang de groeivooruitzichten goed zijn. Indien de bbp-volumegroei de reële rentevoet overtreft vormt ook de bestaande buitenlandse schuld niet direct een bedreiging voor de houdbaarheid van de schuld. Neemt de groei evenwel af, dan kan een omvangrijke buitenlandse schuld instabiel worden, hetgeen het vertrouwen in de Amerikaanse economie ernstig kan bedreigen. Een tweede probleem is ontwikkeling van de particuliere besparingen. Dit probleem is verwant met het probleem van het tekort op de lopende rekening van de betalingsbalans. Immers, een sterke absorptie leidt tot lagere besparingen en een omvangrijke invoer. Een gunstige ontwikkeling in dit verband is echter de status van de federale overheidsuitgaven. De overheid heeft sinds drie jaar een budgetoverschot. Hierdoor is de dreiging van een double deficitscenario voorlopig afgewend.

Vervolgens richten we ons op Japan. De Japanse economie heeft in de laatste vijf jaar een volkomen ander beeld dan de Amerikaanse economie laten zien. In Japan worden nog steeds de gevolgen van de ernstige crisis van 1990 gevoeld. Dit komt hoofdzakelijk tot uiting in een zwakke binnenlandse bestedingsdrang. De slechte leningen drukken de inkomensontwikkeling, het conumentenvertrouwen en tot voor kort ook de investeringen. De investeringen lijken zich echter te herstellen, al is er nog geen beeld van een uitbundig investeringsklimaat. De buitenlandse vraag naar Japanse producten is, ondanks een zeer sterke yen, recentelijk gegroeid. Dit leidt tot een gematigd optimistisch beeld van de Japanse economie, al zal het Japanse herstel in de komende jaren aarzelend zijn. De ogenschijnlijk uitzichtloze situatie van onderbestedingen en deflatie kan door de bui- tenlandse toeneming van de vraag evenwel ten gunste worden gekeerd. Hoewel optimisme wellicht terecht is, zal de Japanse economie nog geruime tijd nodig hebben om de recordgroei uit de jaren zeventig en tachtig te herhalen. De internationale financiële markten erkennen dit en waarderen de Japanse beurs momenteel net zo sterk als vijftien jaar geleden.

De Europese economie ontwikkelt zich veel geleidelijker dan de Amerikaanse of Japanse equivalent. Door de groeifaseverschillen van de diverse Europese economieën is de gemiddelde groei stabieler. Vooral de economieën aan de rand van de Europese Unie, zoals Portugal, Ierland en Nederland, hebben recentelijk relatief sterke groeiprestaties laten zien. In deze landen is er evenwel spanning op de arbeidsmarkten ontstaan, waardoor de inflatie gestegen is. Het Europese renteniveau is in deze landen te laag om vraag en aanbod van goederen in evenwicht te houden. Voor de grotere Europese economieën geldt echter dat het ECB-renteniveau, hoewel in 2000 een aantal malen verhoogd, meer in lijn is met de vraag- en aanbodverhoudingen. In de grotere EU-landen is er immers nog steeds een beeld van werkloosheid. Hierdoor is de groei in de EU weliswaar stabiel, maar evenwel nog lang niet evenwichtig. Hiervoor is het immers nodig dat ook de groei van de werkgelegenheid in de pas loopt met de productiegroei. De gemiddelde groei in het EU-11-gebied beliep in 1999 2,3 procent, in 2000 waarschijnlijk 3,4 procent en valt waarschijnlijk in 2001 weer terug tot 2,6 procent. Het is vooral de export van de grotere Europese economieën die sterk presteert. Ongetwijfeld zijn de gunstige wereldhandel en de zwakke euro van invloed. Voor Duitsland is er nu eindelijk een teken van hervatting van de groei, al lijkt 2001 weer tegen te vallen. Voor Frankrijk geldt dat er een periode van vier jaar met groei te zien is geweest, terwijl ook Italië de laatste twee jaar 3 procent bbp-groei toont. De Britse economie vertoont in lijn met de Amerikaanse economie de eerste tekenen van een tegenvallende conjunctuurontwikkeling. De ongunstige positie van het Pond Sterling is hier mede schuldig aan.

Wat zijn de samenvattende vooruitzichten voor de internationale conjunctuur in 2001? De Amerikaanse economie maakt een landing tot een groeiniveau van maximaal 2 procent. Ook de Europese economieën zullen een lager groeitempo bereiken, al is de teruggang van de groei minder. De Japanse economie blijft op de korte termijn in het slop.

Hierdoor zal het groeiherstel van de wereldhandel niet uit het Verre Oosten kunnen komen. Door dit 
alles is het waarschijnlijk dat de voor ons land relevante wereldhandel in 2001 terug zou kunnen vallen tot ongeveer 7 a 7,5 procent (tegen bijna 10 procent in 2000). Dankzij de ingezette olieprijsdaling en de teruggang van de groei zal het wereldinflatieniveau kunnen dalen. De olieprijs zal naar verwachting tussen de 20 en de 24 dollar per vat schommelen. Bedroeg de groei van de relevante wereldhandelsprijs in 2000 nog ongeveer 6 procent (dankzij de gestegen olieprijs), in 2001 is een lichte daling te verwachten. Dit betekent dat ook de internationale renteontwikkeling (zie hierna) gematigd zal zijn. Er is geen reden om aan te nemen dat er zich belangrijke wijzigingen in de monetaire verhoudingen tussen de VS en de EU zullen voltrekken. Hierdoor zal de reële productiviteitsontwikkeling de wisselkoerspositie bepalen. De snelle groeivertraging in de VS zorgt aldus voor een opwaartse druk op de euro.

Diverse studies hebben aangetoond dat het aannemelijk is dat een evenwichtige eurokoers 1 à 1,1 dollar zou bedragen. Een dollarkoers van 1 euro voor eind 2001 is derhalve waarschijnlijk. Al met al zijn de voruitzichten voor 2001 lang niet zo rooskleurig als de realisaties van 2000. Maar een serieuze aanhoudende recessie in 2002 lijkt onwaarschijnlijk. Dit vermoeden heeft belangrijke consequenties voor het herstel van het consumenten- en productentenvertrouwen.

\section{De Nederlandse economie van 1970 tot 2000}

De Nederlandse economie presteert boven alle verwachtingen. De sterke stijging van het bbp van de afgelopen jaren kwam vooral op het conto van de particuliere consumptiegroei. Zoals bekend is het aandeel van de particuliere consumptie in het bruto binnenlands product meer dan 50 procent. Figuur 3 geeft de samenhang tussen de consumptiegroei (CP) en de groei van het bbp (BBP).

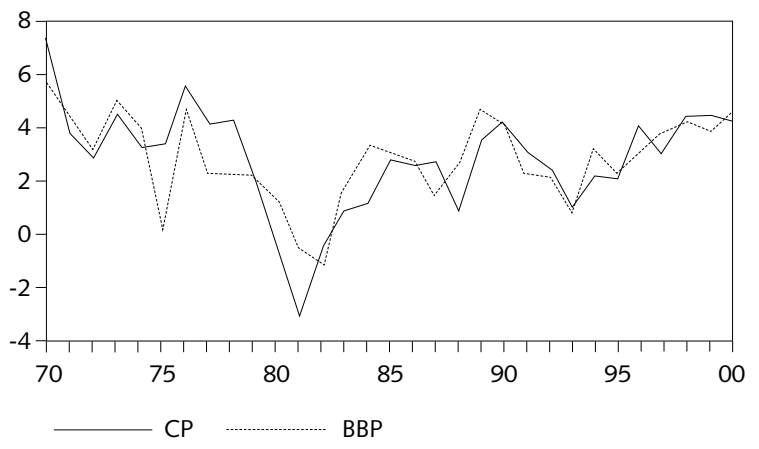

Figuur 3: Groei van de particuliere consumptie (CP) en het bbp in Nederland in procenten. Bron CPB (2000).

Figuur 3 laat zien dat van 1979 tot 1995 de Nederlandse gezinsconsumptie is achtergebleven bij de groei van het bbp. De verklaring hiervan ligt enerzijds in een gematigde inkomensontwikkeling en anderzijds in een gebrek aan consumentenvertrouwen. We behandelen beide verschijnselen hierna. Het beschikbare gezinsinkomen is hoofdzakelijk afhankelijk van twee determinanten: (1) de werkgelegenheid (een werkende verdient meer dan een uitkeringsgerechtigde) en (2) de reële loonontwikkeling. Figuur 4 geeft beide variabelen weer.

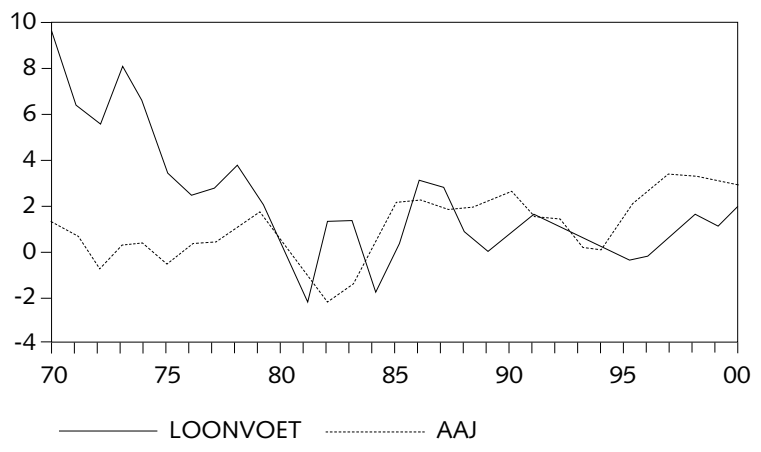

Figuur 4: Groei van de reële loonvoet (contractloon gecorrigeerd voor de prijsindex van de gezinsconsumptie) en de werkgelegenheidsgroei in arbeidsjaren (AAJ) in procenten. Bron CPB, 2000.

Figuur 4 laat duidelijk zien dat na de tweede oliecrisis van 1979 het reële contractloon per saldo nauwelijks gestegen is. Pas in de laatste paar jaar lijkt het er op dat er weer sprake is van een reële loongroei. Dankzij de gematigde loonontwikkeling is de groei van de werkgelegenheid sinds 1983 substantieel (met uitzondering van de laagconjunctuur van 1993). Vooral sinds 1995 is de groei van de werkgelegenheid sterk, hetgeen de opwaartse beweging van de particuliere consumptiegroei verklaart. De gezamenlijke beweging van de werkgelegenheidsgroei en de loonontwikkeling is te danken aan het Akkoord van Wassenaar van 1983. Destijds is afgesproken dat de collectieve loonvorming en het monetaire beleid zouden moeten zijn gericht op stabilisatie van lonen en prijzen.

De ontwikkeling van het beschikbare inkomen van gezinnen geeft de mogelijkheden van de consumptiegroei aan. De index van het consumentenvertrouwen geeft veeleer de plannen van consumenten weer. Hierdoor wordt een dimensie aan de verklaring van het consumptiegedrag toegevoegd. Indien het consumentenvertrouwen toeneemt is de koopbereidheid hoger (koopbereidheid is immers een onderliggende indicator).

Consumentenvertrouwen is voorts een variabele die meer kortetermijnfluctuaties laat zien, waardoor het ook interessant is om op een hogere 
frequentie dan op jaarbasis de data te analyseren. Daartoe is de reeks voor de groei van de particuliere consumptie op kwartaalbasis gebracht (dit kan vanaf 1978 in groeivoeten). Deze reeks is gekoppeld met de reeks consumentenvertrouwen van het CBS. Figuur 5 geeft de relatie tussen beide variabelen.

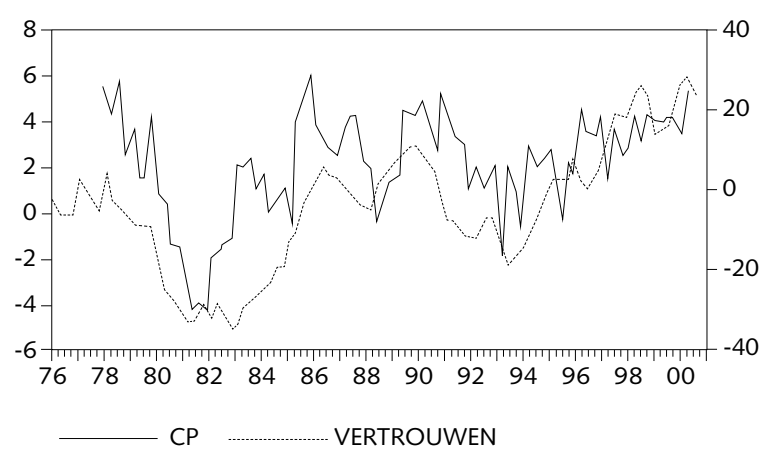

Figuur 5: Groei van de particuliere consumptie (CP, linkerschaal, in procenten) en de index van het consumentenvertrouwen (VERTROUWEN, rechterschaal) op kwartaalbasis. Bron: CBS, Kwartaalrekeningen, Sociaal-Economische Maandstatistiek.

Figuur 5 laat zien dat de trend in de groei van de particuliere consumptie weliswaar wel door het consumentenvertrouwen wordt gezet, maar dat de kortetermijnfluctuaties veel minder goed worden verklaard. De consument lijkt derhalve grilliger in de feitelijke bestedingen dan in de ontwikkeling van het vertrouwen.

De gunstige werkgelegenheidsontwikkeling en de stijging van de reële lonen kunnen evenwel niet volledig de groei van de particuliere consumptie verklaren. Het is waarschijnlijk dat vermogenseffecten eveneens een rol spelen. Dankzij de gunstige ontwikkeling van de beurskoersen tot 1999 is het vermogen van gezinnen toegenomen. Ook de ontwikkeling van de huizenprijzen heeft bijgedragen aan een aanzienlijke toename van het gezinsinkomen. Tussen 1993 en 1999 hebben vermogenseffecten naar alle waarschijnlijkheid gezorgd voor een extra consumptiegroei van ongeveer 1 procentpunt per jaar. Een deel van de vermogenseffecten is tevens terug te vinden in de investeringen, als gezinnen het vermogen hebben aangewend voor structurele verbeteringen aan woningen. Opmerkelijk is dat de consumptieve uitgaven voor voedings- en genotmiddelen sinds 1996 slechts met gemiddeld 1,3 procent per jaar is gestegen. De duurzame consumptie is van 1996 tot en met 2000 met gemiddeld 6,5 procent gestegen. Duurzame consumptie is een typisch procyclische variabele. De volatiliteit van de duurza- me consumptie lijkt op de volatiliteit van bedrijfsinvesteringen. Het is daarom niet verwonderlijk dat de duurzame consumptie in de laatste jaren zo sterk is toegenomen. Het is nog minder verwonderlijk dat een afkoelende economie ook vooral de duurzame consumptie zal ontmoedigen.

De tweede bestedingscomponent is de uitvoer van goederen en diensten. De uitvoer hangt sterk samen met de groei van de relevante wereldhandel (zie figuur 2). Daarnaast is de prijsverhouding van de Nederlandse uitvoer ten opzichte van de concurrerende prijzen van belang. Figuur 6 geeft de ontwikkeling van twee voor de uitvoer relevante variabelen. De eerste variabele is de marktprestatie, de groei van de Nederlandse uitvoer minus de groei van de relevante wereldhandel. Deze variabele geeft aan hoe de Nederlandse uitvoer boven verwachting presteert. De tweede variabele is de prijsconcurrentiepositie, dat is de prijsstijging van de relevante wereldhandel minus de prijsstijging van de Nederlandse uitvoer. De twee variabelen laten de verwachte positieve samenhang zien. De Nederlandse uitvoer presteert beter naarmate de Nederlandse uitvoer relatief goedkoper is. Opvallend is voorts dat de samenhang in de meest recente jaren minder sterk is. Het lijkt er op dat de Nederlandse uitvoer in de jaren 1996-1997 niet ten volle heeft kunnen profiteren van de gunstige prijsontwikkeling.

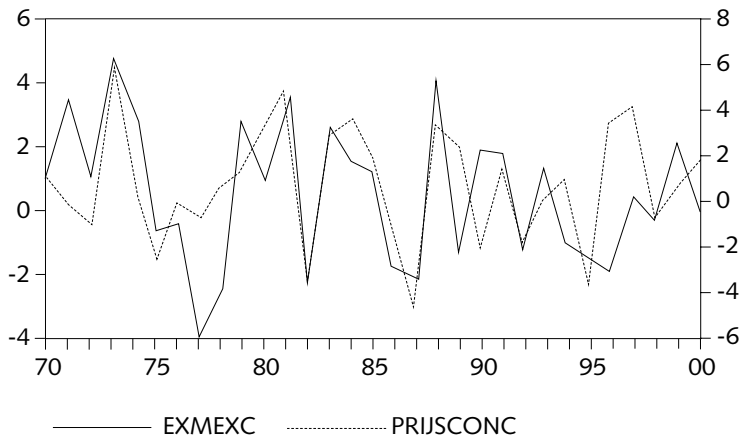

Figuur 6: De Nederlandse uitvoer ten opzichte van de groei van de relevante wereldhandel (EXMEXC, linkerschaal) en de prijsconcurrentiepositie (PRIJSCONC, rechterschaal) in procenten. Bron: $C P B, 2000$.

De groei van de Nederlandse uitvoer is een voorname determinant van de ontwikkeling van het bbp. De Nederlandse uitvoer kent evenwel voor een deel het karakter van doorvoer. De productie van de uitvoer vraagt ook een invoer van grondstoffen en halffabrikaten. De gezamenlijke ontwikkeling van de uitvoer en het bbp bepaalt aldus ook de invoer. Figuur 7 laat de groei van de invoer en de ontwikkeling van het bbp zien. 


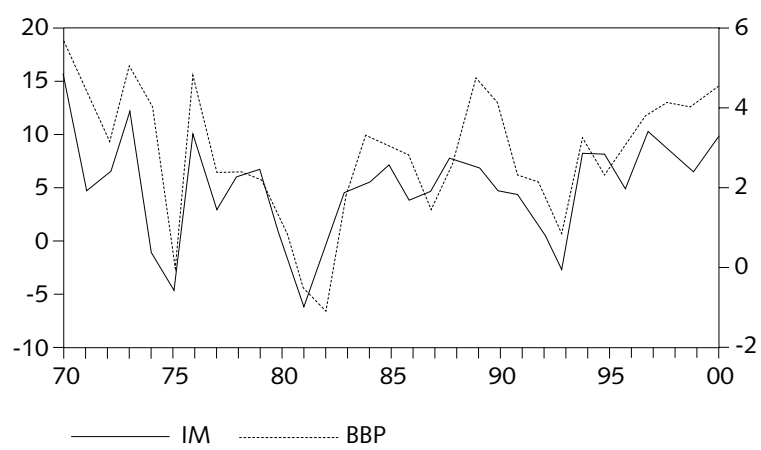

Figuur 7: Groei van de invoer (IM, linkerschaal) en het bruto binnenlands product (BBP, rechterschaal) in procenten. Bron: $C P B, 2000$.

De derde bestedingscomponent wordt gevormd door de investeringen. Investeringen zijn de meest conjunctuurgevoelige bestedingscomponent.

In hoofdlijn bestaan er twee voorname determinanten van de bedrijfsinvesteringen. In de eerste plaats spelen de afzetverwachtingen een belangrijke rol. De verandering van de groei van het bbp is een voorname indicator van de afzetverwachtingen. Ten tweede zijn de investeringskosten van belang. Zoals bekend worden de investeringskosten voor een deel bepaald door de kosten van vreemd vermogen. In figuur 8 wordt de groei van de bedrijfsinvesteringen uitgezet tegen de kapitaalmarktrentevoet.

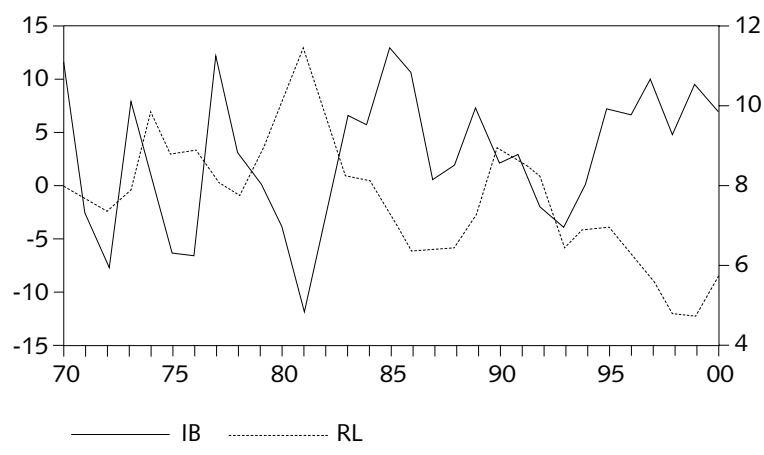

Figuur 8: Groei van de bedrijfsinvesteringen (IB, linkerschaal) en het niveau van de kapitaalmarktrentevoet (RL, rechterschaal) in procenten. Bron: CPB, 2000.

Figuur 8 laat zien dat perioden van een hoge kapitaalmarktrentevoet in de regel samenvallen met een teruggang van de investeringen van bedrijven. De recente daling van de kapitaalmarktrentevoet heeft voor een herstel van de investeringsgroei geleid. Het is immers zo dat de kapitaalmarktrentevoet afhankelijk is van de verwachte inflatie. Het bestrijden van inflatie is derhalve van groot belang voor het zorgen voor een goed investeringsklimaat.

\subsection{Lonen en prijzen}

In een grote economie als de Amerikaanse economie wordt de inflatie grotendeels op binnenlandse markten bepaald. Een vraagoverschot op de goederenmarkt en arbeidsmarkt leidt tot een beweging in opwaartse spiraal van lonen en prijzen. In een kleine open economie met een vaste wisselkoers is de situatie anders. In Nederland zijn relatieve vraagoverschotten van minder belang. De Nederlandse inflatie wordt voor eenderde bepaald door de prijsstijging van de invoer. Vervolgens zijn indirecte belastingen, huren, aardgasprijsverhogingen en de kosten van zorg van belang. De hoofdcomponent van de Nederlandse inflatie wordt gevormd door de arbeidskosten. Lopen de kosten van arbeid per eenheid product te snel op, dan leidt dat tot een doorberekening van die kosten in de inflatie. Hierna wordt inzicht gegeven in de invloed van de invoerprijzen en de arbeidskosten op de inflatieontwikkeling. De invloed van de overheid, hoewel zeker niet onbelangrijk, wordt buiten beschouwing gelaten.

De Nederlandse invoerprijs is gevoelig voor veranderingen van de dollarkoers en de olieprijs. Figuur 9 geeft een beeld van de samenhang tussen invoerprijzen en de verandering van de olieprijs. Recentelijk is de aandacht voor de olieprijs weer toegenomen door de snelle prijsstijging van ruwe olie. De figuur bevat de relatieve verandering van de olieprijs in guldens. In deze variabele is aldus de olieprijs in dollars en de dollar-guldenkoers verwerkt. Figuur 9 laat een duidelijke samenhang zien. Energie is dus direct en indirect een belangrijke kostenpost van de Nederlandse bedrijven.

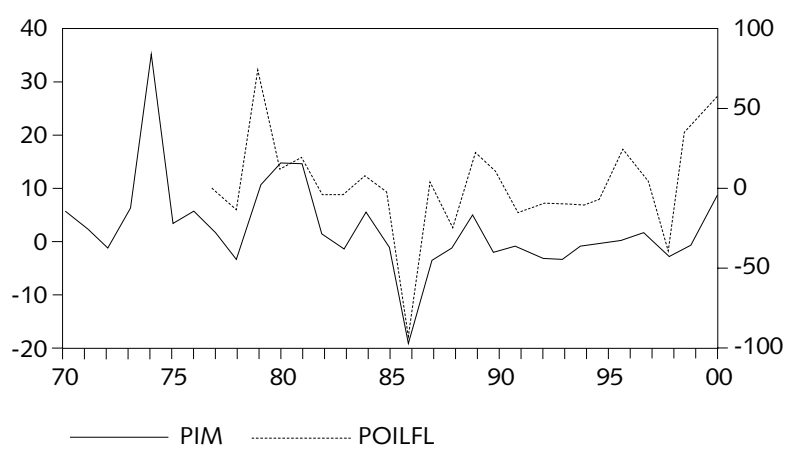

Figuur 9: Relatieve verandering van de invoerprijs (PIM, linkerschaal) en de olieprijs in guldens (POILFL, rechterschaal) in procenten. Bron: CPB, 2000.

Figuur 10 geeft de samenhang tussen de Nederlandse inflatie en de ontwikkeling van de loonkosten per eenheid product. Ook deze figuur 
toont aan dat de loonkosten een voorname determinant van inflatie zijn. Het succes van het Akkoord van Wassenaar is eveneens duidelijk zichtbaar. De figuur geeft voorts duidelijk weer dat de inflatie zich lijkt te stabiliseren op een aanvaardbaar niveau, waarbij het noodzakelijk is dat de loonkosten zich gematigd ontwikkelen. Voor de afgelopen periode lijkt er redelijk aan deze regel voldaan te zijn. Het is evenwel de vraag of dat ook in de nabije toekomst zo zal zijn. In ieder geval zal de Nederlandse inflatie te maken krijgen met een tijdelijke piek in het begin van 2001 door de btw-verhoging en de inkomstenbelastingverlaging.

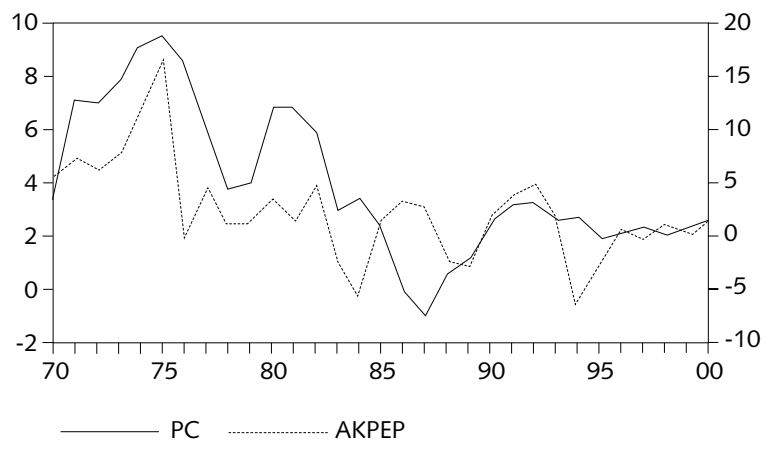

Figuur 10: Relatieve verandering van de consumentprijsindex (PC, linkerschaal) en de arbeidskosten per eenheid product (AKPEP, rechterschaal) in procenten. Bron: $C P B$, 2000.

Als laatste component van de prijsontwikkeling wordt de loonvorming weergegeven. De Nederlandse loonvorming vindt plaats in het afsluiten van collectieve arbeidsovereenkomsten (CAO's). Na een jarenlange periode van reële loonmatiging (zie figuur 2) lijkt het er op dat de loonontwikkeling in de marktsector uitbundiger wordt. Dit vormt geen bedreiging voor de economiche ontwikkeling op de langere termijn indien de reële loonstijging gepaard gaat met een stijging van de arbeidsproductiviteit. Figuur $11 \mathrm{geeft}$ inzicht in deze samenhang. De figuur toont aan dat de groei van de arbeidsproductiviteit ten opzichte van de jaren zeventig is gedaald, hetgeen een minder sterke groei van de reële lonen rechtvaardigt. De arbeidsinkomensquote lijkt zich nu, na een lange periode van waarden van boven de 90 procent (1975-1985) op een niveau van ongeveer 82 procent te stabiliseren. Dit zorgt ervoor dat de winstgevendheid van bedrijven op een voldoende niveau kan worden gehouden. De winstgevendheid van bedrijven garandeert ook een gezondere financiële positie van bedrijven. In de periode van de hoge arbeidsinkomensquote was het aandeel vreemd vermogen van bedrijven te hoog opgelopen. De ruimere winstpositie maakt het mogelijk om een gedeelte van de winst te benutten voor het bekostigen van nieuwe investeringen.

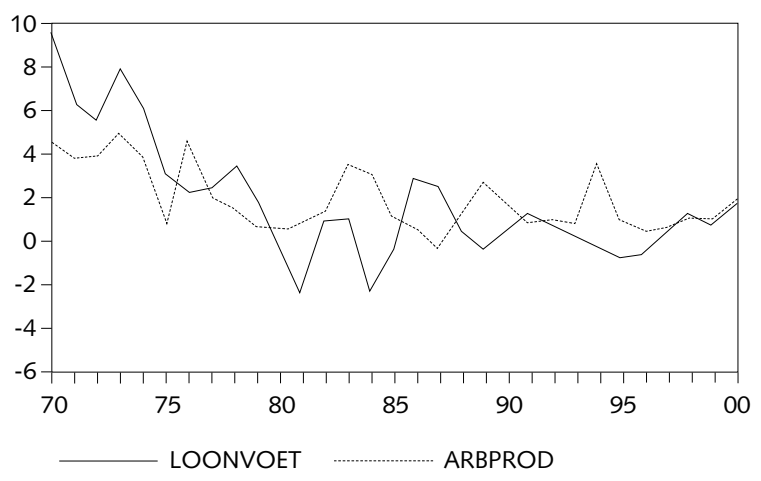

Figuur 11: Relatieve verandering van de reële loonvoet (LOONVOET) en de groei van de arbeidsproductiviteit (ARBPROD) in procenten. Bron: CPB, 2000.

\section{Financiële ontwikkeling}

In deze paragraaf worden de ontwikkelingen van de Nederlandse financiële markten in de afgelopen dertig jaar besproken. Achtereenvolgens komen de geld- en valutamarkt, de obligatiemarkt en de aandelenmarkt aan de orde. We beginnen met de geld- en valutamarkt, omdat hier een direct aanknopingspunt met de reële ontwikkeling ligt. Centrale banken reageren immers op de verwachte ontwikkeling van de productie, de werkloosheid en inflatie. Vervolgens hebben we aandacht voor de rendementen met een langere termijn.

De geld- en valutamarkten hebben ingrijpende veranderingen ondergaan in de afgelopen dertig jaar. De belangrijkste wijzigingen voltrokken zich in de monetaire sfeer. De jaren zeventig worden gekenmerkt door de overgang van vaste naar zwevende wisslkoersen, olieprijsinflatie en betalingsbalansproblemen. De jaren tachtig staan in het teken van de introductie van strakkere monetaire verhoudingen. In de jaren negentig gaat men over op directe beheersing van inflatie. Deze laatste overgang heeft belangrijke gevolgen. We kunnen enerzijds waarnemen dat de wereldinflatie is afgenomen. Anderzijds leidt de directe inflatiebeheersing tot een duidelijke koppeling tussen de reële en de financiële ontwikkeling.

We starten met de valutamarkt en de geldmarkttarieven. In figuur 12 wordt het verschil tussen de Amerikaanse en Nederlandse geldmarktrentevoet tegen het verloop van de dollarkoers uitgezet. Een 
groot écart leidt tot een verwachte appreciatie van de dollar. Zoals uit de figuur is af te lezen lijkt het er op dat de feitelijke dollarkoers zich met enige vertraging aanpast aan de renteontwikkeling. De vertraging is evenwel te lang om redelijk bevonden te worden. Immers de geld- en valutamarkten kenmerken zich door hoge aanpassingssnelheden. Het ligt voor de hand dat naast het renteverschil ook verschillen in geldaanbod, groei van het bbp en inflatieverschillen een rol spelen. De laatste variabelen zijn in staat om ook op de korte termijn een verklaring van koersbewegingen te geven. Het renteverschil is evenwel een grootheid die van belang is voor het toekomstige verloop van de dollarkoers.

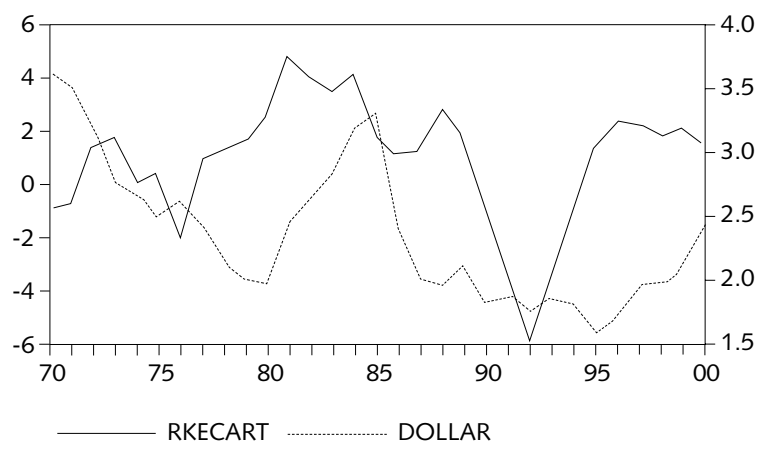

Figuur 12: Verschil tussen de Amerikaanse en Nederlandse geldmarktrentevoet (RKECART, linkerschaal, in procenten) en de dollar-guldenkoers (DOLLAR, rechterschaal, in guldens). Bron: IMF, International Financial Statistics.

De geldmarktrentevoeten in de VS en Europa worden gebruikt als instrument van het monetaire beleid. In het laatste decennium gebruiken de meeste centrale banken de geldmarktrentevoet als instrument om direct inflatie te beheersen. Men gaat ervan uit dat de centrale banken een zogenoemde Taylor-regel hanteren. De Taylor-regel luidt als volgt:

$$
R=\alpha\left(Y-Y^{*}\right)+\beta\left(P^{e}-P^{*}\right)+c
$$

waarin R de geldmarktrentevoet is, $Y$ het bbp, $Y^{*}$ het natuurlijke (evenwichtige) bbp, $P^{e}$ de verwachte inflatie en $P^{*}$ de gewenste inflatie. Indien de verwachte inflatie boven de doelwaarde ligt wordt de rentevoet verhoogd. Hetzelfde geldt voor een zeer omvangrijke productieverhoging. Omdat de Wet van Okun stelt dat de output-gap $Y-Y^{*}$ negatief gecorreleerd is met de werkloosheidsgap $U-U^{*}$ gebruiken we de laatste indicator om de paramaters voor de VS en Europa vast te stellen met behulp van:

$$
R=-\alpha\left(U-U^{*}\right)+\beta\left(P^{e}-P^{*}\right)+c
$$

Voor Europa veronderstellen we dat $U^{*}=6$ en $P^{*}=2$. Voor de VS is de natuurlijke werkloosheid $U^{*}=4$ en de evenwichtige inflatie $P^{*}=3$. Met behulp van gegevens voor de periode 1986-2000 vinden we voor Europa voor $\alpha=0.35, \beta=2$ en $c=5$. Voor de VS vinden we $\alpha=0.65, \beta=1$ en $c=6$. Dit impliceert dat we voor Europa met een verwachte inflatie van 2 en een verwachte werkloosheid van 8 procent een rentevoet van 4,3 procent verwachten en voor de VS met een verwachte inflatie van 2,5 procent en een licht oplopende werkloosheid van 4,5 procent een rentevoet van ruim 5 procent voorzien. Het afnemende écart tussen de VS en Europa dient eveneens als aanwijzing van een dalende dollarkoers. Het gebruikmaken van de Taylor-regel is tegenwoordig algemeen geaccepteerd. Men dient evenwel op te merken dat de exacte timing van rentewijzigingen moeilijk is aan te geven.

Voor de bespreking van de kapitaalmarktrentevoet beginnen we met een eenvoudige grafische illustratie van de termijnstructuur (het verschil tussen de kapitaal- en geldmarktrentevoet) en de ontwikkeling van het bbp. Figuur 13 geeft een illustratie voor Nederland. We hebben voor de duidelijkheid de termijnstructuur één jaar vertraagd. Immers, de helling van de termijnstructuur weerspiegelt een voorspelling van de toekomstige conjunctuur. Hoewel de samenhang aan het einde van de periode minder goed is, is het verloop van de variabelen opvallend identiek. Een oplopende conjunctuur wordt geassocieerd met een hogere inflatieverwachting, hetgeen zich zou kunnen vertalen in een steilere termijnstructuur.

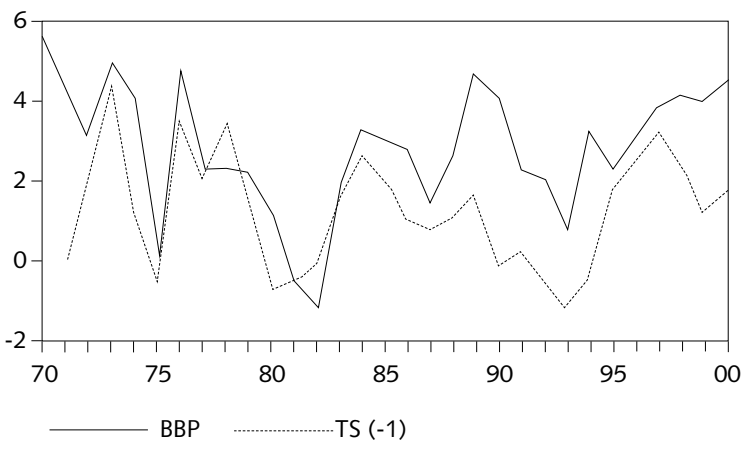

Figuur 13: De groei van het bbp (BBP) en de termijnstructuur (1 jaar vertraagd, TS) in procenten. Bron: CPB, 2000.

Het lijkt derhalve voor de hand te liggen om de kapitaalmarktrentevoet in verband te brengen met de ontwikkeling van de Europese conjunctuur. Indien de bestedingen afnemen en er relatief meer besparingen vrijkomen, zal de reële rentevoet kunnen dalen. Indien ook de inflatieverwachting 
gematigd is, hetgeen het geval zal zijn in een afzwakking van de economische ontwikkeling, en er zich geen additionele risicofactoren voordoen, is een gematigde renteontwikkeling waarschijnlijk.

Wat betreft de aandelenmarkt is het eveneens interessant om de relatie tussen het aandelenrendement en de conjuncturele ontwikkeling te analyseren. Figuur 14 geeft het aandelenrendement weer als de relatieve verandering van de CBS-index plus het dividendrendement en de ontwikkeling van het bbp. Wederom is de ontwikkeling van het aandelenrendement een jaar vertraagd.

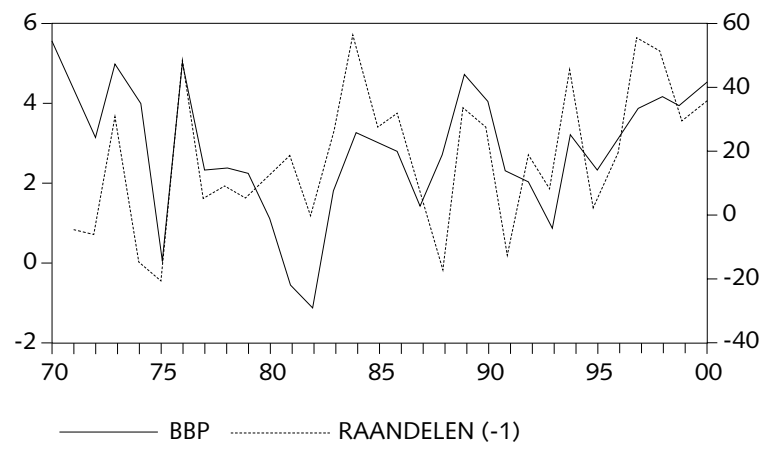

Figuur 14: Groei van het bbp (BBP, linkerschaal) en het aandelenrendement (RAANDELEN, een jaar vertraagd, rechterschaal) in procenten. Bron: CPB, 2000 en De Nederlandsche Bank.

Blijkbaar is het aandelenrendement ook een variabele die conjunctuurgevoelig is. Indien de conjunctuur aantrekt is de winstontwikkeling beter. Bovendien zijn aandelen relatief ongevoeliger voor het nadeel van een aantrekkende inflatie. Omgekeerd lijkt een daling van het aandelenrendement tot nagenoeg 0 in 2000 een voorbode van een verwachte conjuncturele afzwakking. Wil men het aandelenrendement voor 2001 voorspellen dan is het nodig om de bbp-ontwikkeling van 2002 te voorzien. Hierboven is aangegeven dat een licht optimisme voor 2002 op de markt overheerst.

\section{Voorspellingen voor 2001}

In de hiervoor geschetste analyse van de afgelopen dertig jaar is een aantal verbanden geschetst dat kan worden gebruikt om inzicht te krijgen in de ontwikkeling van de economie in 2001. We volgen hier hetzelfde pad als hierboven beschreven is en beginnen met de internationale conjunctuur.

Voor 2001 wordt alom een afzwakking van de Amerikaanse economie verwacht. Deze verzwakking heeft zich in de tweede helft van $2000 \mathrm{al}$ ingezet en zal zich in 2001 verder voltrekken.
De Amerikaanse groei komt uit op ongeveer 2 procent. De inflatie in de VS zal eveneens dalen tot een niveau van 2,5 procent. Hierdoor zal de werkloosheid licht oplopen en volgens de Taylorregel is het hoogstwaarschijnlijk dat de geldmarktrentevoet in de VS zal dalen met ongeveer 100 basispunten. In de maand januari 2001 heeft deze rentedaling zich al voltrokken. Voor Japan verwachten we nog geen sterk herstel. Voor de EU-11 ligt een geringe groeivertraging in het verschiet. Desalniettemin kan de bbp-groei nog ongeveer 3 procent bedragen. De inflatie zal licht boven de doelstelling van de ECB blijven: 2,25 procent. De werkloosheid zal niet snel verder dalen en rond de 8 procent blijven. Hierdoor is het volgens de Taylor-regel waarschijnlijk dat de Europese rentevoet in 2001 licht zal dalen met tussen de 25 en de 50 basispunten. Per saldo zal de euro ten opzichte van de dollar appreciëren.

De voor Nederland relevante wereldhandel zwakt af, hetgeen de exportgroei tot 7 à 8 procent zal doen dalen. De binnenlandse bestedingen zullen minder hard groeien. Dit zal zich vooral uiten in een daling van de investeringssgroei en de groei van duurzame consumptie. Per saldo zal de Nederlandse economie in 2001 met een krappe 3 procent groeien. De belastingverlaging zal immers voor een aanvullende bestedingsimpuls zorgen. Voor 2002 is het de vraag of de groeivertraging zal doorzetten. Vooralsnog is daar geen directe aanwijzing voor te vinden. De meeste internationale organisaties voorzien een voorspoedige ontwikkeling in 2002 in Europa. Als gevolg van de belastingverlaging zal de Nederlandse economie tijdelijk met een licht oplopende inflatie te maken krijgen. Zoals bekend is dat niet schadelijk omdat de voorspellingen van de toekomstige Nederlandse inflatie redelijk gunstig zijn.

\section{LITERAT U UR}

Centraal Planbureau, 2000, Macro Economische Verkenning 2001, SDU: ‘s-Gravenhage. 